\title{
Ernest Hemingway's The Sun Also Rises: An Image of Optimism and Light
}

\author{
Dr. Mayurkumar Mukund Bhai Solanki \\ Assistant Professor of English \\ Growmore College of Engineering \\ Himatnagar, Gujarat, India \\ mmsmodasa@yahoo.com
}

\begin{abstract}
Ernest Heminway was interested in the delineation of characters as well as different facets of man's life through the characters of the novels. Hemingway's first novel, The Sun Also Rises is about ups and down of man's life. The novel gives an image of emptiness and futility of life. As the novel progresses, Hemingway presents a light picture of man's life in the heavy odds of life. Hemingway tries to assert the fact that there is always light after darkness and joy after sorrow. This research paper is a sincere effort to justify Hemingway's philosophy of optimism and light.

Ernest Hemingway, a popular American writer, produced three masterpieces of novels like: The Sun Also Rises, A Farewell to Arms, and The Old man and the Sea. Hemingway intends to depict the different facets of human life through the characters of his novels. Hemingway's A Farewell to Arms deals with the theme of the futility of war and The Old Man and the Sea is about man's struggle against destiny. However, Hemingway mainly intends to display man's helplessness against destiny, he highlights a ray of hope through the character of old man. His first novel The Sun Also Rises is a mixture of Hemingway's pessimism with a touch of hope and light.
\end{abstract}


Life always moves between two poles of hope and despair. Generally, man expects good things to be happened in life but sometime unexpected things happen in life that create and despair in man's life. Gloominess leads man to disaster. Only hope keeps man moving during his hard times. T.S. Eliot, an American poet expresses his gloomy feelings about the barrenness of man's life in his The Waste Land, a long narrative poem in English verse in which he seems to emphasize man's need of love and support in the midst of difficulty.

Hemingway's The Sun Also Rises deals with the themes of optimism and pessimism. In the title, 'The Sun' signifies 'hope' and 'Also Rises' denotes ups and down of man's life. The title of the novel is taken from the Bible. Hemingway writes:

One generation passed away, and another cometh; but the earth abided forever forever. The sun ariseth and the sun goeth down, and haseth to the place where he arose. The wind goeth towards the South and turneth about unto the North; it whirleth about continually and the wind return the again according to his circuits. All the rivers run into the sea; yet the sea is not full; unto the place porom whence the rivers come, they return again. (Hemingway, p.3).

Hemingway seems to mourn over the lost generation, but he welcomes coming new generation. He favours the philosophy of everyday is a new day, nothing is permanent whether success or failure, joy or sorrow, ups and down. Man is generally wavering between past and future hence he cannot live in present. Such thing makes a man unhappy and sad. Omar Khayyam, a Persian poet in his work The Rubaiyat, a collection of verses writes:

Ah, fill the cup: - what boots it to repeat

How time is slipping underneath our feet:

Unborn To-morrow and dead yesterday, Why fret about them if To-day be sweet! (http://www.bobforrestweb.co.uk/The_Rubaiyat/verse_by_verse_noteshtm) 
Khayyam seems to favour the philosophy of 'Caese the Day' in the above verse. Man should not worry about his future and should not dwell on his past but enjoy the present moment.

Hemingway’s The Sun Also Rises was published in 1926 that displays how American and the British expatriates travel from Paris to the festival in Pampola to watch the running of the bulls and the bullfights. Jake Barnes, a protagonist of the novel, is unable to have sex because of his war wound. On the other hand, Lady Brett Ashley is presented as an expatriate American Journalist living in Paris and is having numerous love affairs with men. The Sun Also Rises is divided into three books. In book I, Hemingway talks about Jack and Robert Cohn and their illegitimate relationship with a prostitute. Book II deals with the story of Jack joined by Bill Gorton and the third book shows the characters in the aftermath of the fiesta.

Hemingway's The Sun Also Rises presents a picture of emptiness through the empty barges.

Brett had not been in the bar either and so looked for her upstairs on my way out, and took a taxi for the Café select. Crossing the Seine I saw a string of barges being towed empty down the current, riding high, the bargemen at the sweeps as they came towards the bridge. (Shams, p. 28).

The emptiness of human life is revealed through things in the novel. The struggle of novel's characters is a struggle of human beings. On the other hand, such things indicate the futility of man's life.

The image of emptiness again asserted in chapter 16 of the novel in the following manners:

He sat down and looked at her across the table. I went out. The hard eyed people at the bull fighter table watched me go. It was not pleasant. When I came back and 
looked in the café, twenty minutes later, Brett Pedro Romero were gone. The coffee glasses and the three empty cognac glasses were on the table. A waiter came with a cloth and picked up the glasses and mopped off the table. (Shams, p. 29)

Brett and Pedro are moving closer to eachother. However, the images of empty glasses display the emptiness of human life. As the novel progresses, we do get the image of happiness, growth and fruitfulness. The atmosphere of freedom and gaiety is associated with fishing in the Irati river in Spain.

We stayed five days at Burguete and had good fishing. The nights were cold and the days were hot, and there was always a breeze even in the heat of the day. It was hot enough so that it felt good to wade in a cold stream, and sun dried you when you came out and sat on the bank. We found a stream with a pool deep enough to swim in. in the evening we played three-handed bridge with an Englishman named Harris, who had walked over from Saint Jean Pied de Port and was stopping at the inn for the fishing. He was very pleased and went with us twice to the irate river. (Shams, p.32) The cold night indicates happiness and hot days denote sadness of human beings. It seems that there are plenty of opportunities for human beings to go ahead in life. In this way, the river is a symbol of hope and happiness.

Hemingway describes the joy of the Basque peasants, raw and vigorous and virile: People were coming into the square from all sides, and down the street we herd and pipes and the fifes and the drums coming. They were playing the riau -riau music, the pipes shrill and drums pounding, and behind them came the men and the boys dancing. When the fifers stopped they all crouched down in the street, and when the reed pipes and the fifes shrilled, and the flat, dry hollow drums tapped it out again, they all went up in the air dancing. In the crowd you saw only the heads and the shoulders of the dancers going up and down. (Shams, p. 38). 
The instruments of music denote the joy of common man and man's real happiness lies in doing work. Music always gives pleasure to man and it reduces the stress of man. It seems that music is useful to come over the problem of man's unhappiness.

On the whole, Hemingway attempts to highlight happiness and sadness of human beings. One should see the positive aspect of the novel. Positivity makes man's life fruitful and it gives man a way of life. One has to accept joy and sorrow and go ahead in life. No one remains in the darkness for a long time if one tries to overcome from such a difficulty. The ups and downs of Hemingway's characters indicate darkness and light in the life of human beings. There is always a ray of hope in the darkness but one has to stay positive during hard times. 


\section{References}

Hemingway, Ernest, The Sun Also Rises, Penguin publication, New Delhi, 1974, p.3.

Shams, Ishteyaque, The Novels of Ernest Hemingway: A Critical Study, Atlantic Publishers and Distributors, New Delhi, 2002, p. 26.

Ibid,28.

Ibid,29.

Ibid,32.

Ibid,38.

https://en.wikipedia.org/wiki/The_Sun_Also_Rises

http://www.bobforrestweb.co.uk/The_Rubaiyat/verse_by_verse_notes.htm 